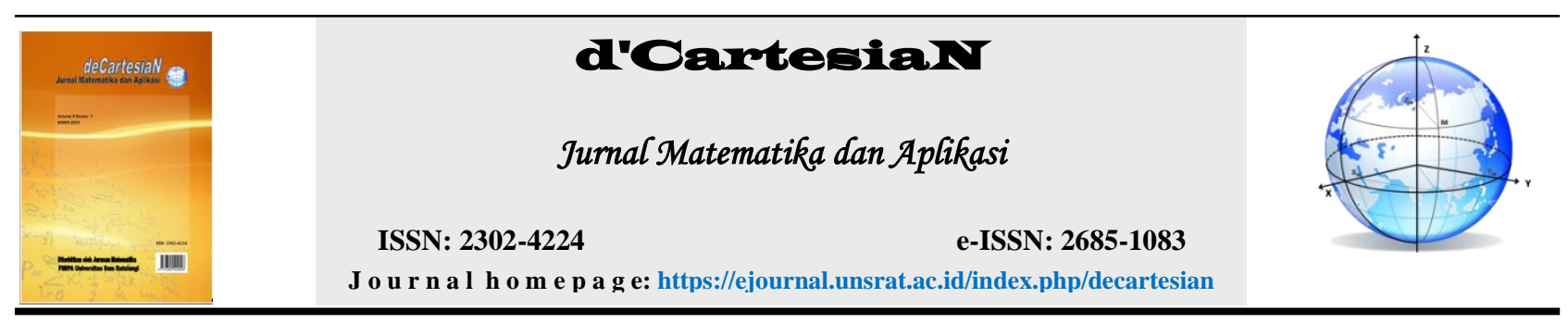

\title{
Penentuan Status Pemanfaatan dan Pengelolaan Ikan Tongkol (Auxis rochei) yang Tertangkap di Perairan Bolaang-Mongondow Selatan dan Bolaang- Mongondow Timur Sulawesi Utara
}

\author{
Ladi B. Deeng1, Hanny A. H. Komalig1, John S. Kekenusa ${ }^{1 *}$ \\ ${ }^{1}$ Jurusan Matematika-Fakultas Matematika dan Ilmu Pengetahuan Alam-Universitas Sam Ratulangi Manado,Indonesia
}

${ }^{*}$ Corressponding author : johnskekenusa@unsrat.ac.id

\begin{abstract}
A B S T R A K
Ikan Tongkol (Auxis rochei), perlu dikelola dengan baik karena walaupun sebagai sumberdaya hayati yang dapat diperbaharui, namun dapat mengalami tangkap-lebih (overfishing), deplesi ataupun kepunahan. Salah satu cara pendekatan dalam pengelolaan sumberdaya ikan ialah dengan pemodelan. Penelitian ini bertujuan untuk mengetahui status pemanfaatan dan pengelolaan ikan tongkol serta tangkapan maksimum lestari atau Maximum Sustainable Yield (MSY) dengan menggunakan Model Produksi Surplus. Data hasil tangkapan dan upaya tangkap ikan tongkol dikumpulkan dari Dinas Kelautan dan Perikanan Kabupaten Bolaang-Mongondow Selatan dan Bolaang-Mongondow Timur Sulawesi Utara selama tahun 2009-2017. Model Produksi Surplus yang dapat digunakan untuk menelaah hasil tangkapan ikan tongkol ialah model Schaefer. Hasil tangkapan maksimum lestari ikan tongkol $C_{M S Y}$ sebesar 869,556 ton per tahun, di peroleh pada tingkat upaya tangkap $E_{\text {opt }} 933$ trip. Untuk tahun 2017 besarnya tingkat pemanfaatan sebesar $64,95 \%$ dengan demikian produksi masih dapat di tingkatkan, dengan tingkat pengupayaan $73,74 \%$ menunjukan tingkat pengupayaan yang belum optimal dan masih dapat di tingkatkan.
\end{abstract}

\section{INFO ARTIKEL}

Diterima : 25 September 2019

Diterima setelah revisi : 30 Oktober 2019

Tersedia online : 28 Oktober 2019

\section{Kata Kunci:}

Ikan tongkol

Model Produksi Surplus

Kabupaten Bolaang-Mongondow

Selatan dan Bolaang-Mongondow

Timur

\begin{abstract}
A B S T R A C T
Bonito (Auxis rochei), needs to be managed properly because even though it is a renewable biological resource, it can experience overfishing, depletion or extinction. One way to approach the management of fish resources is by modeling. This research is aiming to determine the status of utilization and management of bonito and maximum sustainable yield (MSY) using the Surplus Production Model. Data on catching and efforts to catch bonito is collected from the Marine and Fisheries Service of South Bolaang-Mongondow Regency and East Bolaang-Mongondow of North Sulawesi. The surplus production model that can be used to determine the catch of bonito is the Schaefer model. The maximum sustainable catch of bonito is 869.556 tons per year, obtained at the level of catching effort of 933 trips. For 2017 the level of utilization is $64.95 \%$ so that production can still be increased, with a level of effort of $73.74 \%$ indicating the level of effort that is not optimal and can still be increased.
\end{abstract}

\section{ARTICLE INFO}

Accepted : 25 September 2019

Accepted after revision : 30

September 2019

Available online : 28 October 2019

\section{Keywords:}

Bonito

Surplus Production Model

Bolaang-Mongondow South and

Bolaang-Mongondow East Districts

\section{PENDAHULUAN}

Ikan tongkol (Auxis rochei) tergolong sumberdaya perikanan pelagis penting dan merupakan salah satu komoditi ekspor nir-migas. Kegiatan perikanan tongkol di Indonesia masih dipusatkan pada masalah penangkapan, sedangkan perhatian terhadap aspek biologi dan lingkungannya baru berkembang beberapa tahun terakhir ini.

Perairan Bolaang-Mongondow Selatan (Bolsel) dan Bolaang-Mongondow Timur (Boltim) sebagai bagian dari Sulawesi Utara, selama ini titik berat pengembangan perikanan termasuk pengusahaan tongkol ialah dalam hal menangkap atau mengeksploitasi sumberdaya perikanan. Data mengenai tingkat pemanfaatan suatu sumberdaya ikan sangat penting, karena akan menentukan status apakah pemanfaatan sumberdaya tersebut kurang optimal, optimal, atau berlebih. Pemanfaatan sumberdaya ikan yang berlebihan akan mengancam kelestariannya. Dengan mengetahui tingkat pemanfaatan sumberdaya tongkol, diharapkan dapat dilakukan pengelolaan yang terencana dan lestari.

Salah satu cara pendekatan dalam memprediksi pengelolaan sumberdaya ikan ialah melalui pemodelan. Model yang paling sederhana dalam dinamika populasi ikan ialah Model Produksi Surplus (MPS). Model ini, pada umumnya digunakan dalam penilaian stok ikan hanya dengan menggunakan data hasil tangkapan dan upaya tangkap yang umumnya tersedia. Melalui MPS, dapat diprediksi potensi sumberdaya ikan, jumlah maksimum hasil tangkapan yang menjamin kelestarian sumberdaya, serta alokasi 
jumlah optimum upaya-tangkap (trip kapal) yang dioperasikan agar sumberdaya tetap lestari dan ekonomis.

Penelitian tentang potensi dan status pemanfaatan ikan tongkol masih jarang dilakukan dibanding dengan ikan cakalang. Hasil penelitian tentang tingkat pemanfaatan dan pengusahaan perikanan cakalang di perairan Bolaang-Mongondow Sulawesi Utara menunjukkan bahwa telah terjadi tangkap-lebih (overfishing) untuk perikanan cakalang di wilayah ini [1].

Penelitian tentang status pemanfaatan ikan tongkol di perairan Sulawesi Utara, telah diawali dengan penelitian di perairan Sangihe, Talaud, dan SiauTagulandang-Biaro (SITARO). Di perairan Talaud untuk tahun 2012 tingkat pemanfaatan sebesar 94,86\% yang mengindikasikan adanya tangkap-lebih (overfishing), dengan tingkat pengusahaan 193,99\% yang menunjukkan suatu tingkat pengusahaan yang tidak efisien [2]. Untuk perairan SITARO pada tahun 2013 tingkat pemanfaatan sebesar $103,80 \%$ yang mengindikasikan adanya tangkap-lebih (overfishing), dengan tingkat pengusahaan $110,56 \%$ yang menunjukkan suatu tingkat pengusahaan yang tidak efisien [3]. Dalam pemanfaatan sumberdaya ikan di laut termasuk tongkol, salah satu permasalahan utama ialah seberapa banyak ikan yang dapat ditangkap tanpa mengganggu keberadaan stok, atau bagaimana panen biomassa ikan dapat dimaksimalkan tanpa mengganggu prospek eksploitasi di masa mendatang.

\section{Bolaang-Mongondow Selatan dan Bolaang- Mongondow Timur}

Kabupaten Bolaang-Mongondow Selatan adalah sebuah kabupaten di Provinsi Sulawesi Utara, Indonesia dengan pusat pemerintahan berada di Bolaang Uki. Kabupaten ini dibentuk berdasarkan Undang-Undang Nomor 30 Tahun 2008 yang merupakan pemekaran dari Kabupaten BolaangMongondow. Peresmian dilakukan oleh Menteri Dalam Negeri, Mardiyanto di Manado pada hari Selasa, 30 September 2008. Penduduk Kabupaten BolaangMongondow Selatan berdasarkan proyeksi penduduk tahun 2018 sebanyak 65.127 jiwa dengan luas wilayah mencapai $1.932,30 \mathrm{~km}^{2}$. Produksi ikan tangkap laut di tahun 2017 mencapai 2.592,o ton. Angka ini meningkat 25 persen dari 2016 [4].

Kabupaten Bolaang-Mongondow Timur sebelumnya merupakan bagian dari Kabupaten Bolaang-Mongondow. Kemudian, melalui Undangundang Nomor 29 Tahun 2008, Bolaang MongondowTimur dimekarkan menjadi sebuah kabupaten yang otonom. Sejak berdirinya, Kabupaten BolaangMongondow Timur telah terjadi perkembangan yang cukup signifikan dalam bidang pemerintahan, dimana pada awalnya terdiri dari 5 (lima) Kecamatan. Pada akhir tahun 2017 sudah menjadi 7 kecamatan. Penduduk Kabupaten Bolaang- Mongondow Timur berdasarkan proyeksi penduduk tahun 2017 sebanyak 70.610 jiwa dengan luas wilayah mencapai $910.176 \mathrm{~km}^{2}$. Produksi ikan tangkap laut di tahun 2017 mencapai 1.225,34 ton [5].

\section{Model Produksi Surplus}

Model yang paling sederhana dalam dinamika populasi ikan ialah model produksi surplus yang memperlakukan populasi ikan sebagai biomassa tunggal yang tidak dapat dibagi, yang tunduk pada aturan- aturan sederhana dari kenaikan dan penurunannya. Model produksi ini tergantung pada 4 macam besaran, yaitu : biomassa populasi pada suatu waktu tertentu $\mathrm{t}$ $\left(B_{t}\right)$, tangkapan untuk suatu waktu tertentu $\mathrm{t}\left(C_{t}\right)$, upaya tangkap pada waktu tertentu $\mathrm{t}\left(E_{t}\right)$, dan laju pertumbuhan alami konstan (r) [6]. Model ini pertama kali dikembangkan oleh Schaefer, yang bentuk awalnya sama dengan model pertumbuhan logistik.

Persamaan surplus produksi terdiri dari beberapa konstanta yang dipengaruhi oleh pertumbuhan alami, kemampuan alat tangkap, dan daya dukung lingkungan. Konstanta-konstanta tersebut diduga dengan menggunakan model-model penduga parameter biologi dari persamaan surplus produksi, yaitu model : Equilibrium Schaefer, Disequilibrium Schaefer, Schnute, dan Walter - Hilborn. Berdasarkan keempat model tersebut dipilih yang paling sesuai atau best fit dari pendugaan yang lain [7].

Rumus-rumus model produksi surplus hanya berlaku apabila parameter slope (b) bernilai negatif, yang berarti penambahan upaya tangkap akan menyebabkan penurunan hasil tangkapan per upaya tangkap. Apabila parameter b nilainya positif, maka tidak dapat dilakukan pendugaan besarnya stok maupun upaya optimum, tetapi hanya dapat disimpulkan bahwa penambahan upaya tangkap masih memungkinkan untuk meningkatkan hasil tangkapan [8].

Pendugaan upaya penangkapan optimum $\left(E_{\text {opt }}\right)$ dan hasil tangkapan maksimum lestari $\left(C_{M S Y}\right)$ didekati dengan Model Produksi Surplus. Antara hasil tangkapan per satuan upaya $\left(C P U E_{t}\right)$ dan upaya tangkap (effort) dapat berupa hubungan linear maupun eksponensial. Model Produksi Surplus terdiri dari 2 model dasar yaitu Model Schaefer (hubungan linear) dan Model Gompertz yang dikembangkan oleh Fox dengan bentuk hubungan eksponensial [9].

\section{Model Schaefer}

Model Produksi Surplus pertama kali dikembangkan oleh Schaefer, yang bentuk awalnya sama dengan model pertumbuhan logistic [9]. Model tersebut ialah :

$$
\frac{d B_{t}}{d t}=G\left(B_{t}\right)=r B_{t}\left(1-\frac{B_{t}}{K}\right)
$$

Persamaan ini belum memperhitungkan pengaruh penangkapan, sehingga Schaefer menuliskan kembali menjadi :

$$
\frac{d B_{t}}{d t}=r B_{t}\left(1-\frac{B_{t}}{K}\right)-C_{t}
$$

dengan K ialah daya dukung lingkungan perairan, dan $C_{t}$ ialah tangkapan yang dapat ditulis sebagai:

$$
C_{t}=q E_{t} B_{t}
$$

dengan $\mathrm{q}$ sebagai koefisien ketertangkapan (catchability), dan $E_{t}$ menunjukkan upaya tangkap. Persamaan ini ditulis menjadi :

$$
\frac{C_{t}}{E_{t}}=q B_{t}=C P U E
$$

Dari persamaan diferensial (2), tangkapan optimum dapat dihitung pada saat $\frac{d B_{t}}{d t}=0$, yang berbentuk:

$$
\begin{aligned}
& r B_{t}\left(1-\frac{B_{t}}{K}\right)-C_{t}=0, \text { atau } \\
& C_{t}=r B_{t}\left(1-\frac{B_{t}}{K}\right)=q E_{t} B_{t}
\end{aligned}
$$

Dari persamaan (3) dan (5) diperoleh nilai $B_{t}$ sebagai berikut :

$$
B_{t}=\mathrm{K}\left(1-\frac{q E_{t}}{r}\right)
$$


Sehingga persamaan (5) menjadi :

$$
\begin{aligned}
C_{t} & =q K E_{t}\left(1-\frac{q E_{t}}{r}\right) \\
& =q K E_{t}-\frac{q^{2} K}{r} E_{t}{ }^{2}
\end{aligned}
$$

Persamaan (7) disederhanakan lagi oleh Schaefer menjadi :

$$
\begin{aligned}
& \frac{C_{t}}{E_{t}}=a-b E_{t}, \quad \text { atau } \\
& C_{t}=a E_{t}-b E_{t}{ }^{2}
\end{aligned}
$$

sedangkan $\mathrm{a}=\mathrm{q} \mathrm{K}$ dan $\mathrm{b}=\frac{q^{2} K}{r}$. Hubungan linear ini yang digunakan secara luas untuk menghitung $C_{M S Y}$ melalui penentuan turunan pertama $C_{t}$ terhadap $E_{t}$ untuk mencari solusi optimal, baik untuk tangkapan maupun upaya tangkap. Turunan pertama $C_{t}$ terhadap $E_{t}$ adalah $: \frac{d C_{t}}{d E_{t}}=a-2 b E_{t}$, sehingga diperoleh dugaan $E_{\text {opt }}$ (upaya tangkapan optimum) dan $C_{M S Y}$ (tangkapan maksimum lestari) masing-masing :

$$
E_{\text {opt }}=\frac{a}{2 b}=\frac{r}{2 q}
$$

dengan memasukkan nilai $E_{\text {opt }}$ pada persamaan (8), akan diperoleh $C_{M S Y}$ sebagai berikut:

$$
\begin{aligned}
C_{M S Y}= & a E_{t}-b E_{t}{ }^{2} \\
& =a\left(\frac{a}{2 b}\right)-b\left(\frac{a}{2 b}\right)^{2} \\
& =\frac{a^{2}}{4 b}
\end{aligned}
$$

dengan mensubtitusi $\mathrm{a}=\mathrm{qK}$ dan $\mathrm{b}=\frac{q^{2} K}{r}$, akan diperoleh

$$
C_{M S Y}=\frac{a^{2}}{4 b}=\frac{q^{2} K^{2}}{4 q^{2} K / r}=\frac{r K}{4}
$$

Nilai-nilai a dan $\mathrm{b}$ diduga melalui pendekatan metode kuadrat terkecil yang umum digunakan untuk menduga koefisien persamaan regresi sederhana. Selanjutnya, dengan memasukkan nilai $E_{\text {opt }}$ pada persamaan (6) diperoleh biomassa optimum $B_{M S Y}$ sebagai berikut:

$$
\begin{aligned}
B_{M S Y} & =K-\frac{K q}{r} E_{o p t} \\
& =K-\frac{K q}{r}\left(\frac{r}{2 q}\right) \\
& =K-\frac{K}{2} \\
& =\frac{K}{2}
\end{aligned}
$$

Nilai-nilai parameter $\mathrm{q}, \mathrm{K}$, dan $\mathrm{r}$ dapat dihitung dengan menggunakan algoritma Fox [10], sebagai berikut :

$$
q_{t}=\ln \left[\left|\frac{\left(z U_{t}{ }^{-1}+\frac{1}{b}\right)}{\left(z U_{t+1}{ }^{-1}+\frac{1}{b}\right)}\right|\right] /(z)
$$

dimana $\mathrm{z}=-(\mathrm{a} / \mathrm{b}) / \mathrm{E}^{*}, \mathrm{E}^{*}=\left(E_{t}+E_{t+1}\right) / 2, U_{t}=$ $\frac{C_{t}}{E_{t}}$, dan nilai q adalah rata-rata geometrik dari nilai $q_{t}$. Dari nilai a, b, dan q, selanjutnya dapat dihitung nilai $\mathrm{K}$ dan r.

\section{Model Fox}

Model ini memiliki beberapa karakteristik yang berbeda dari model Schaefer, yaitu pertumbuhan biomassa mengikuti model pertumbuhan Gompertz. Penurunan CPUE terhadap upaya tangkap (E) mengikuti pola eksponensial negatif [11]. Model ini menghasilkan garis lengkung bila $\frac{C_{t}}{E_{t}}$ diplot terhadap $E_{t}$, akan tetapi bila $\frac{C_{t}}{E_{t}}$ diplot dalam bentuk logaritma terhadap $E_{t}$, akan diperoleh garis lurus :

$$
\ln \frac{C_{t}}{E_{t}}=a-b E_{t} \text { atau } \frac{C_{t}}{E_{t}}=\exp \left(a-b E_{t}\right)
$$

Kedua model ini mengikuti asumsi bahwa $\frac{C_{t}}{E_{t}}$ menurun dengan meningkatnya upaya tangkap. Nilai $\frac{C_{t}}{E_{t}}$ selalu lebih besar dari nol untuk semua nilai $E_{t}$. Hubungan antara tangkapan $\left(C_{t}\right)$ dengan upaya tangkap $\left(E_{t}\right)$ ialah :

$$
C_{t}=E_{t} \cdot \exp \left(a-b E_{t}\right)
$$

Upaya optimum diperoleh dengan menyamakan turunan pertama $C_{t}$ terhadap $E_{t}$ sama dengan nol:

$$
E_{\text {opt }}=\frac{1}{b}
$$

Hasil tangkapan maksimum lestari $\left(C_{M S Y}\right)$ didapat dengan memasukkan nilai upaya optimum ke dalam persamaan (14), dan diperoleh :

$$
C_{M S Y}=\frac{1}{b} e^{a-1}
$$

Nilai dugaan parameter a dan $b$ pada persamaan (13) dapat diperoleh dengan menggunakan persamaan regresi sederhana. Rumus-rumus tersebut hanya berlaku bila parameter slope (b) bernilai negatif, yang berarti bahwa penambahan jumlah upaya tangkap akan menyebabkan penurunan CPUE. Apabila dalam perhitungan nilai slope (b) positif, maka tidak dapat dilakukan pendugaan stok maupun besarnya upaya optimum, tetapi hanya dapat disimpulkan bahwa penambahan upaya tangkap masih menambah hasil tangkapan.

\section{Model Schnute}

Model ini mengemukakan versi lain dari model produksi surplus yang bersifat dinamis serta deterministic [12]. Metode Schnute dianggap sebagai modifikasi dari model Schaefer dalam bentuk diskret. Bentuk dasar dari model Schnute dikembangkan dari persamaan (2) dan (3), yakni sebagai berikut :

$$
\frac{d B_{t}}{B_{t}}=\left\{r-\frac{r B_{t}}{K}-q E_{t}\right\} d t
$$

Jika persamaan (17) diintegralkan dan dilakukan satu langkah setahun kedepan akan diperoleh :

$$
\ln \left(B_{t+1}\right)-\ln \left(B_{t}\right)=r-\frac{r}{K} \overline{B_{t}}-q \overline{E_{t}}
$$

Dari persamaan (3) diperoleh :

$$
\begin{aligned}
B_{t} & =\frac{c_{t}}{E_{t}} / q \\
& =\frac{U_{t}}{q} \\
\overline{B_{t}} & =\frac{\overline{U_{t}}}{q}
\end{aligned}
$$

Jika persamaan (18) disederhanakan dengan $\overline{U_{t}}$ adalah rata-rata CPUE dan $\overline{E_{t}}$ rata-rata upaya tangkap per tahun, maka akan diperoleh persamaan berikut :

$$
\begin{aligned}
\ln \left(\frac{U_{t+1}}{U_{t}}\right) & =r-\frac{r}{q K} \overline{U_{t}}-q \overline{E_{t}}, \text { atau } \\
\ln \left(\frac{U_{t+1}}{U_{t}}\right) & =r-\frac{r}{q K}\left(\frac{U_{t}+U_{t+1}}{2}\right)-q\left(\frac{E_{t}+E_{t+1}}{2}\right) \\
& =a-b\left(\frac{U_{t}+U_{t+1}}{2}\right)-c\left(\frac{E_{t}+E_{t+1}}{2}\right)
\end{aligned}
$$

dimana $\mathrm{a}=\mathrm{r}, \mathrm{b}=\frac{r}{q K}$, dan $\mathrm{c}=\mathrm{q}$, adalah penduga parameter koefisien regresi berganda.

Nilai dugaan parameter biologi dapat diduga dengan rumus sebagai berikut ini :

$$
\begin{aligned}
& \mathrm{b}=\frac{r}{q K} \\
& \mathrm{~K}=\frac{r}{b q} \\
& C_{M S Y}=\frac{a^{2}}{4 b c}=\frac{r^{2}}{4\left(\frac{r}{K q}\right) q}=\frac{r K}{4} \\
& E_{O p t}=\frac{r}{2 q}
\end{aligned}
$$




\section{Model Walter - Hilborn}

Walter dan Hilborn, mengembangkan jenis lain dari model produksi surplus, yang dikenal sebagai model regresi [13]. Model Walter-Hilborn ini, menggunakan persamaan diferensial sederhana, dengan persamaan sebagai berikut :

$$
B_{t+1}=B_{t}+r B_{t}\left(1-\frac{B_{t}}{K}\right)-C_{t}
$$

Jika $C_{t}=q B_{t} E_{t}$, dan $B_{t}=\frac{U_{t}}{q}$, serta $U_{t}=\frac{C_{t}}{E_{t}}$ menyatakan CPUE (Catch Per Unit Effort), maka persamaan (21) dapat diformulasi kembali sebagai berikut :

$$
\frac{U_{t+1}}{q}=\frac{U_{t}}{q}+\frac{r U_{t}}{q}\left(1-\frac{U_{t}}{K_{q}}\right)-U_{t} E_{t}
$$

Penyusunan kembali persamaan (22) dengan memindahkan $\frac{U_{t}}{q}$ ke sisi kiri dan mengalikan dengan $\frac{q}{U_{t}}$, akan diperoleh persamaan model Walter-Hilborn sebagai berikut :

$$
\begin{aligned}
\frac{U_{t+1}}{U_{t}}-1 & =r-\frac{r}{K q} U_{t}-q E_{t} \\
& =a-b U_{t}-c E_{t}
\end{aligned}
$$

dimana $\mathrm{a}=\mathrm{r}, \mathrm{b}=\frac{r}{K q}$, dan $\mathrm{c}=\mathrm{q}$, adalah penduga parameter koefisien regresi berganda.

\section{Model Clarke Yoshimoto Pooley (CYP)}

Pendugaan parameter biologi untuk model produksi surplus dapat pula dilakukan melalui teknik pendugaan yang dikemukakan oleh Clarke, Yoshimoto, dan Pooley [14]. Parameter-parameter yang diduga ialah $\mathrm{r}$, K, dan q, dengan model yang dinyatakan sebagai berikut :

$$
\begin{aligned}
& \ln \left(U_{t+1}\right)=\left(\frac{2 r}{2+r}\right) \ln (q K)+\frac{2-r}{2+r} \ln \left(U_{t}\right)- \\
& \frac{q}{2+r}\left(E_{t}+E_{t+1}\right)
\end{aligned}
$$

dimana : $\frac{2 r}{2+r}=a^{\prime}, a=a^{\prime} \ln (q K), b=\frac{2-r}{2+r}, c=\frac{q}{2+r}$ dengan demikian persamaan (24) dapat ditulis dalam bentuk :

$$
\begin{aligned}
\ln \left(U_{t+1}\right) & =a^{\prime} \ln (q K)+b \ln \left(U_{t}\right)-c\left(E_{t}+E_{t+1}\right) \\
& =a+b \ln \left(U_{t}\right)-c\left(E_{t}+E_{t+1}\right)
\end{aligned}
$$

Pendugaan parameter untuk persamaan (25) dilakukan dengan metode OLS (Ordinary Least Squre) untuk meregresi $\ln \left(U_{t+1}\right)$, dengan $\ln \left(U_{t}\right)$ dan $\left(E_{t}+E_{t+1}\right)$.

\section{Metode Ordinary Least Squared (OLS) Penduga Parameter Regresi Linear}

Analisis regresi adalah suatu metode statistika yang digunakan untuk menganalisa hubungan antara beberapa variabel. Model linier untuk pengamatan ke-i secara umum ditulis sebagai berikut:

$$
Y_{i}=\beta_{0}+\beta_{1} X_{i 1}+\beta_{2} X_{i 2}+\cdots+\beta_{k} X_{i k}+u_{k} ; i
$$$$
=1,2, \ldots, n \text {, }
$$

dan dalam notasi matriks dapat ditulis sebagai

$$
Y=X \beta+u
$$

Pendugaan parameter pada model liner regresi biasanya dilakukan dengan Metode

Kuadrat Terkecil (MKT) atau disebut juga penduga Ordinary Least Squared (OLS) [15].

Metode penduga Ordinary Least Squares (OLS) adalah metode pendugaan yang paling umum digunakan untuk menduga suatu model regresi populasi atas dasar model regresi sampel. Prinsip pendugaan parameter dengan metode OLS adalah dengan meminimumkan jumlah kuadrat galat. Jika diberikan suatu model $\mathrm{Y}=\mathrm{X} \beta+\mathrm{u}, E(\mathrm{u})=0$ dan $\operatorname{Var}(\mathrm{u})=\sigma^{2} \mathrm{I}$

$$
\hat{\beta}_{\text {ols }}=\left(\mathrm{X}^{\prime} \mathrm{X}\right)^{-1} \mathrm{X}^{\prime} \mathrm{Y},
$$

dimana nilai tengah dan varian dari penduga OLS adalah

$$
\begin{aligned}
& E(\hat{\beta})=\beta, \\
& \operatorname{Cov}(\hat{\beta})=\sigma^{2}\left(X^{\prime} X\right)^{-1}
\end{aligned}
$$

\section{METODOLOGI PENELITIAN}

Penelitian ini dilakukan pada tahun 2018 di Bolaang-Mongondow Selatan dan Bolaang-Mongondow Timur juga di Jurusan Matematika FMIPA Universitas Sam Ratulangi Manado. Data yang dikumpulkan ialah data sekunder tentang hasil tangkapan ikan tongkol dan upaya tangkap diambil dari Dinas Kelautan dan Perikanan Bolaang-Mongondow Selatan dan BolaangMongondow Timur selama tahun 2009-2017.

\section{Definisi operasional variabel yang dianalisis}

Data (variabel) yang digunakan untuk analisis Model Produksi Surplus ialah data hasil tangkapan ( $C_{t}$, dalam ton) per tahun dan upaya tangkap ( $E_{t}$, dalam trip) per tahun, serta CPUE $\left(\frac{C_{t}}{E_{t}}\right)$ dengan pendugaan parameter yang berbeda-beda mengikuti persamaan yang ada di tinjauan pustaka . Definisi operasional data (variabel) yang digunakan untuk analisis model produksi surplus ialah sebagai berikut :

1. Hasil tangkapan $\left(C_{t}\right)$ : berat ikan yang didaratkan (ton) pada tahun ke t

2. Upaya Tangkap $\left(E_{t}\right)$ : jumlah kapal motor penangkap ikan yang mendaratkan hasilnya ditempat pendaratan (trip) pada tahun ket

$$
\begin{aligned}
& \text { 3. } \operatorname{CPUE}\left(\frac{C_{t}}{E_{t}}\right) \\
& \text { (ton/trip) pada tahun ket }
\end{aligned}
$$

Model Produksi Surplus yang dikaji ialah : model Schaefer, model Fox, model Schnute, model Walter-Hilborn, dan model Clarke Yoshimoto Pooley (CYP). Dari model-model tersebut dievaluasi dan dipilih model yang terbaik.

\section{Metode Analisis Data}

Model penduga yang dianalisis dan dievaluasi ialah : model Schaefer, model Fox, model Schnute, model Walter-Hilborn, dan model Clarke Yoshimito Pooley (CYP). Prosedur pendugaan parameter (koefisien) model-model tersebut mengikuti rumusrumus seperti yang dikemukakan pada tinjauan pustaka. Berdasarkan hasil evaluasi secara statistika yakni (kesesuaian tanda, nilai $R^{2}$, nilai validasi, dan signifikansi koefisien regresi model), akan diperoleh suatu model yang terbaik sebagai penduga. Dari model tersebut dapat dihitung nilai $C_{M S Y}$, upaya-tangkap optimum $E_{\text {Opt }}$, tingkat pemanfaatan, tingkat pengusahaan sumberdaya perikanan tongkol.

Penelitian ini mencakup pembentukan model, pendugaan parameter (koefisien), serta pengujian model. Pengujian model meliputi pendugaan parameter dan pemeriksaan kesahihan (validasi) model. Kegiatan ini diawali dengan pengumpulan data empirik. Tahapan berikutnya ialah pendugaan parameter, dan pengujian hipotesis. Pengujian kesahihan (validasi) model menggunakan tolak ukur keakuratan (accuracy), ketelitian (precision), dan ketegaran (robustness) [16]. Ukuran akurasi dapat digunakan koefisien determinasi maka diperoleh penduga OLS sebagai berikut 
$\left(R^{2}\right)$, sedangkan untuk ukuran ketelitian dan ketegaran digunakan taraf-nyata $\propto$ (alpha) untuk uji F dan uji-t [17]. Taraf-nyata $(\propto)$ yang digunakan ialah $5 \%$.

\section{HASIL DAN PEMBAHASAN}

Hasil Analisis Regresi untuk Model Produksi Surplus disajikan pada lampiran 1.1 - 1.5, yang diuraikan sebagai berikut :

\section{Model Schaefer}

Dari hasil analisis diperoleh persamaan regresi $\frac{C_{t}}{E_{t}}=1,865-0,001 E_{t}$, dengan nilai koefisien determinasi $\left(R^{2}\right)=0,751$ dan tingkat signifikansi o,oo2 jadi $\mathrm{p}<0,05$. Dengan demikian model produksi penduga hasil tangkapan untuk model Schaefer sesuai persamaan (8) ialah:

$C_{t}=1,865 E_{t}-0,001 E_{t}^{2}$

Tabel 1. Hasil Tangkapan, Upaya Tangkap, dan CPUE Ikan Tongkol di Perairan Bolsel dan Boltim Tahun 2009-2017

\begin{tabular}{|c|c|c|c|}
\hline Tahun & $\begin{array}{c}\text { Tangkapan } \\
\text { (ton) } \boldsymbol{C}_{\boldsymbol{t}}\end{array}$ & $\begin{array}{c}\text { Upaya } \\
\text { (trip) } \\
\boldsymbol{E}_{\boldsymbol{t}}\end{array}$ & $\begin{array}{c}\boldsymbol{C P U E}=\frac{\boldsymbol{C}_{\boldsymbol{t}}}{\boldsymbol{E}_{\boldsymbol{t}}} \\
\text { (ton/trip) } \\
\boldsymbol{U}_{\boldsymbol{t}}\end{array}$ \\
\hline 2009 & 504,5 & 424 & $\mathbf{1 , 1 8 9 9}$ \\
\hline 2010 & 562,3 & 451 & $\mathbf{1 , 2 4 6 8}$ \\
\hline 2011 & 637,4 & 517 & $\mathbf{1 , 2 3 2 9}$ \\
\hline 2012 & 691,7 & 604 & 1,1452 \\
\hline 2013 & 695,9 & 651 & 1,0690 \\
\hline 2014 & 611,7 & 662 & 0,9240 \\
\hline 2015 & 650,5 & 671 & 0,9694 \\
\hline 2016 & 582,6 & 682 & 0,8543 \\
\hline 2017 & 564,8 & 688 & 0,8209 \\
\hline $\begin{array}{c}\text { Rata- } \\
\text { rata }\end{array}$ & $\mathbf{6 1 1 , 2 6 7}$ & $\mathbf{5 9 4 , 4 4}$ & $\mathbf{1 , 0 5 0 3}$ \\
\hline
\end{tabular}

\section{Model Fox}

Pada model Fox dilakukan analisis regresi sederhana antara Ln CPUE dengan upaya tangkap untuk data pada tabel 1. Dari hasil analisis diperoleh persamaan regresi $\operatorname{Ln} \frac{C_{t}}{E_{t}}=0,817-0,001 E_{t}$, dengan nilai koefisien determinasi $\left(R^{2}\right)=0,723$ dan tingkat signifikansi $\mathrm{p}<0,05$. Penduga hasil tangkapan untuk model Fox sesuai persamaan (14) ialah : $C_{t}=E_{t} \cdot e^{\left(0,817-0,001 E_{t}\right)}$

\section{Model Schnute}

Untuk model Schnute dilakukan analisis regresi antara $\operatorname{Ln}\left(\frac{U_{t+1}}{U_{t}}\right)$ dengan $\left(U_{t+1}+U_{t}\right) / 2$ dan $\left(E_{t+1}+E_{t}\right) / 2$ berdasarkan persamaan (19). Dari hasil analisis diperoleh persamaan regresi $\operatorname{Ln}\left(\frac{U_{t+1}}{U_{t}}\right)=0,963-$ $0,413\left(U_{t+1}+U_{t}\right) / 2-0,001\left(E_{t+1}+E_{t}\right) / 2$ dengan nilai koefisien determinasi $\left(R^{2}\right)=0,306$ dan semua koefisien regresi tidak signifikan.

\section{Model Walter - Hilborn}

Pada model Walter - Hilborn dilakukan analisis regresi antara regresi $\left(U_{t+1} / U_{t}\right)-1$ dengan $U_{t}$ dan $E_{t}$ sesuai persamaan (23). Dari hasil analisis diperoleh persamaan regresi $\left(U_{t+1} / U_{t}\right)-1=1,206-$
$0,599 U_{t}-0,001 E_{t}$ dengan nilai koefisien determinasi $\left(R^{2}\right)=0,635$ dan koefisien regresi tidak semua signifikan.

\section{Model Clarke Yoshimoto Pooley (CYP)}

Pada model CYP dilakukan regresi berganda antara $\operatorname{Ln}\left(U_{t+1}\right)$ dengan $\operatorname{Ln}\left(U_{t}\right)$ dan $\left(E_{t}+E_{t+1}\right)$ sesuai persamaan (25). Dari hasil analisis diperoleh persamaan regresi $\quad \operatorname{Ln}\left(U_{t+1}\right)=0,573+0,498 \operatorname{Ln}\left(U_{t}\right)-$ $0,000489\left(E_{t}+E_{t+1}\right.$ dengan nilai koefisien determinasi $\left(R^{2}\right)=0,920$ dan koefisien regresi tidak semua signifikan.

\section{Evaluasi Model Produksi Surplus}

Jadi untuk model Schaefer, model Fox, model Schnute, Model Walter - Hilborn dan model Clarke Yoshimoto Pooley (CYP) telah memperoleh nilai koefisien regresi yang sesuai dengan tanda yang dipersyaratkan.

Untuk model Schaefer dan model fox telah memperoleh nilai signifikan. Sedangkan untuk model yang lain, tidak semua signifikan. Kemudian untuk nilai $\left(R^{2}\right)$ yang paling besar yakni model CYP sedangkan untuk nilai validasi relatif kecil diperoleh model Walter - Hilborn.

Tabel 2. Validasi Model Produksi Surplus Ikan Tongkol di Perairan Bolsel dan Boltim

\begin{tabular}{|l|c|c|c|c|c|}
\hline & $\begin{array}{c}\text { Model } \\
\text { Schaefer }\end{array}$ & $\begin{array}{c}\text { Model } \\
\text { Fox }\end{array}$ & $\begin{array}{c}\text { Model } \\
\text { Schnute }\end{array}$ & $\begin{array}{c}\text { Model } \\
\text { Walter- } \\
\text { Hilborn }\end{array}$ & $\begin{array}{c}\text { Model } \\
\text { CYP }\end{array}$ \\
\hline $\begin{array}{l}\text { Kesesuaian } \\
\text { Tanda }\end{array}$ & Sesuai & Sesuai & Sesuai & Sesuai & Sesuai \\
\hline Nilai $\boldsymbol{R}^{2}$ & $\mathbf{0 , 7 5 1}$ & 0,723 & 0,306 & 0,635 & 0,920 \\
\hline $\begin{array}{l}\text { Nilai } \\
\text { Validasi }\end{array}$ & $\mathbf{0 , 2 2 5 3}$ & 0,2071 & 0,1810 & 0,0672 & 0,2594 \\
\hline $\begin{array}{l}\text { Signifikansi } \\
\text { Koefisien } \\
\text { Regresi }\end{array}$ & Signifikan & Signifikan & $\begin{array}{c}\text { Tidak } \\
\text { Signifikan }\end{array}$ & $\begin{array}{c}\text { Tidak } \\
\text { Semua } \\
\text { Signifikan }\end{array}$ & $\begin{array}{c}\text { Tidak } \\
\text { Semua } \\
\text { Signifikan }\end{array}$ \\
\hline
\end{tabular}

Sesuai hasil pada tabel 2, terlihat hasil yang paling sesuai ialah model Schaefer dengan nilai $R^{2}$ cukup besar $\left(R^{2}=0,751\right)$ dan validasi (nilai residual) relatif kecil. Dari model Schaefer di peroleh nilai a $=1,865$ dan nilai $b=0,001$, dengan persamaan (9) dan (10) dapat di hitung nilai upaya optimum $\left(E_{\text {opt }}\right)$ dan tangkapan maksimum lestari $\left(C_{M S Y}\right)$ sebagai berikut :

$E_{\text {opt }}=\frac{a}{2 b}=\frac{1,865}{2(0,001)}=932,5 \approx 933$ trip per tahun.

$C_{M S Y}=\frac{a^{2}}{4 b}=\frac{1,865^{2}}{4(0,001)}=869,556$ ton per tahun.

Ini berarti bahwa untuk menjaga kelestarian sumber daya perikanan tongkol secara teknis dan biologis, dalam setahun jumlah unit penangkapan tidak boleh melebihi 933 trip. Untuk menjaga kelestarian sumber daya ikan tongkol di perairan Bolaang-Mongondow Selatan dan Bolaang-Mongondow Timur, maksimum ikan tongkol yang dapat di tangkap sebesar 869,556 ton pertahun.

Selanjutnya dari nilai $E_{o p t}$ dan $C_{M S Y}$ dapat di hitung tingkat upaya penangkapan dan tingkat pemanfaatan ikan tongkol untuk tahun tertentu misalkan tahun 2017, sebagai berikut:

Tingkat upaya tahun $2017=\frac{E_{2017}}{E_{o p t}} \times 100 \%$

$$
=\frac{688}{933} \times 100 \%=73,74 \%
$$

Tingkat pemanfaatan tahun $2017=\frac{C_{2017}}{C_{M S Y}} \times 100 \%$

$$
=\frac{564.8}{869,556} \times 100 \%=64,95 \% \text {. }
$$


Dari hasil perhitungan, ternyata upaya tangkap ikan tongkol di perairan Bolsel dan Boltim pada tahun 2017, masih belum efisien. Tingkat pemanfaatan untuk tahun 2017, belum mencapai optimum (baru sekitar 64,95\%) dan masih dapat di tingkatkan.

\section{KESIMPULAN DAN SARAN Kesimpulan}

Hasil tangkapan maksimum lestari ikan tongkol $C_{M S Y}$ sebesar 869,556 ton per tahun, di peroleh pada tingkat upaya tangkap $E_{\text {opt }} 933$ trip. Untuk tahun 2017 besarnya tingkat pemanfaatan sebesar 64,95\% dengan demikian produksi masih dapat di tingkatkan, dengan tingkat pengupayaan $73,74 \%$ menunjukan tingkat pengupayaan yang belum optimal dan masih dapat di tingkatkan. Model Produksi Surplus yang dapat digunakan untuk menelaah hasil tangkapan ikan tongkol di perairan Bolaang Mongondow Selatan dan Bolaang Mongondow Timur ialah model Schaefer, dengan persamaan : $\hat{C}_{t}=1,865 E_{t}-0,001 E_{t}^{2}$.

\section{Saran}

1) Dalam menerapkan model produksi surplus di suatu perairan, tidak hanya langsung menggunakan satu model tertentu saja, tetapi menggunakan beberapa model yang di pilih berdasarkan kriteria statistika. Kriteria tersebut antara lain: kesesuaian tanda, nilai koefisien determinasi $R^{2}$, nilai validasi, dan signifikansi koefisien regresi.

2) Perikanan ikan tongkol di perairan BolaangMongondow Selatan dan Bolaang-Mongondow Timur, masih dapat ditingkatkan baik tingkat pemanfaatan maupun upaya tangkapnya.

\section{REFERENSI}

[1] Kekenusa, J.S., V.N.R. Watung, D. Hatidja. 2014. Penentuan Status Pemanfaatan dan Skenario Pengelolaan Ikan Cakalang (Katsuwonus pelamis) Yang Tertangkap di Perairan Bolaang-Mongondow, Sulawesi Utara. Jurnal ilmiah sains 14(1): 9-17.

[2] Kekenusa, J.S., Marline S. Paendong, Winsy Ch.D. Weku, and Sendy B. Rondonuwu. 2015. Determination of the Status of Utilization and Management Scenarios Bonito (Auxis rochei) Caught in the Talaud Waters North Sulawesi. Sci. J. of Applied Mathematics and Statistics; 3(2):39-46.

[3] Kekenusa, J.S., S.B. Rondonuwu, M.S. Paendong, dan W.Ch.D. Weku. 2014. Penentuan Status Pemanfaatan dan Skenario Pengelolaan Ikan Tongkol (Auxis rochei) di Perairan Kabupaten SiauTagulandang-Biaro, Sulawesi Utara. Jurnal ilmiah sains 14(2): 136-145.

[4] BPS 2019. Kabupaten Bolaang Mongondow Selatan Dalam Angka 2019. http:// bolselkab.bps.go.id [06 September 2019]

[5] BPS 2018. Kabupaten Bolaang Mongondow Timur Dalam Angka 2018. http:// boltimkab.bps.go.id [06 September 2019]

[6] Boer, M., dan K.A. Azis. 1995. Prinsip-prinsip Dasar Pengelolaan Sumberdaya Perikanan Melalui
Pendekatan Bio-Ekonomi. Jurnal Ilmu-ilmu Perairan dan Perikanan. 3(2):109-119.

[7] Coppola G., and S. Pascoe. 1996. A Surplus Production Model with a non-linear Catch-Effort Relationship. (Research Paper 105) Center for the Economics and Managemant of Aquatic Resources University of Portsmouth.

[8] Sparre , P. and S.C. Venema. 1999. Introduksi Pengkajian Stok Ikan Tropis. Buku 1 Manual. Terjemahan J. Widodo. I.G.S. Merta, S. Nurhakim, dan M. Badrudin. Pusat Penelitian dan Pengembangan Perikanan, Badan Penelitian dan Pengembangan Pertanian (Kerjasama dengan Organisasi Pangan dan Pertanian Perserikatan Bangsa-bangsa). Jakarta.

[9] Gulland, J.A. 1983. Fishing and Stock of Fish at Iceland. Agric. Fish Food, Invest. (Ser.2) 23(4): 52 70.

[10] Sularso, A. 2005. Alternatif Pengelolaan Perikanan Udang di Laut Arafura. [Disertasi]. Sekolah Pascasarjana Institut Pertanian, Bogor.

[11] Fox, W.W. 1970. An Exponential Surplus Yield Model for Optimazing Exploited Fish Population. Trans. Am. Fish Soc. 99(1):80-88.

[12] Schnute, J. 1977. Improved Estimates from the Schaefer Production Models : Theoretical Considerations: J. Fish. Res. Board Can., 34:583663.

[13] Tinungki, G. M. 2005. Evaluasi Model Produksi Surplus dalam Menduga Hasil Tangkapan Maksimum Lestari untuk Menunjang Pengelolaan Perikanan Lemuru Di Selat Bali. [Disertasi]. Sekolah Pascasarjana Institut Pertanian, Bogor.

[14] Fauzi, A., dan S. Anna. 2005. Pemodelan Sumberdaya Perikanan dan Kelautan untuk Analisis Kebijakan. PT. Gramedia Pustaka Utama, Jakarta.

[15] Helmi, I., Rahmat S., dan Maiyastri 2014. Perbandingan Penduga Ordinary Least Squares (OLS) dan Generalized Least Squares (GLS) Pada Model Regresi Linier Dengan Regresor Bersifat Stokastik dan Galat Model Berautokorelasi. Jurnal Matematika UNAND. 3(4):168-176.

[16] Meyer, W.J. 1987. Concepts of Mathematical Modelling. McGraw-Hill Inc. New York.

[17] Zar, J.H. 1984. Biostatistical Analysis. PrenticeHall, New Jersey. 
Penentuan Status Pemanfaatan dan Pengelolaan Ikan Tongkol (Auxis rochei) yang Tertangkap di Perairan BolaangMongondow Selatan dan Bolaang-Mongondow Timur Sulawesi Utara

d'Cartesian Jurnal Matematika dan Aplikasi, Vol. 9, No. 1, (Maret 2020): 1-7

Ladi Beatriex Deeng (deengladi@gmail.com)

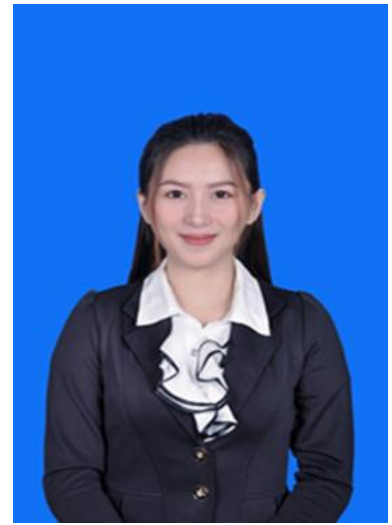

Lahir dan tinggal di Sion

Tompasobaru, Sulawesi Utara. Menempuh pendidikan tinggi Program Studi Matematika dan Ilmu Pengetahuan Alam Universitas Sam Ratulangi Manado. Tahun 2019 adalah tahun terakhir ia menempuh studi. Makalah ini merupakan hasil penelitian skripsinya yang di publikasikan.

John S. Kekenusa (johnskekenusa@unsrat.ac.id)

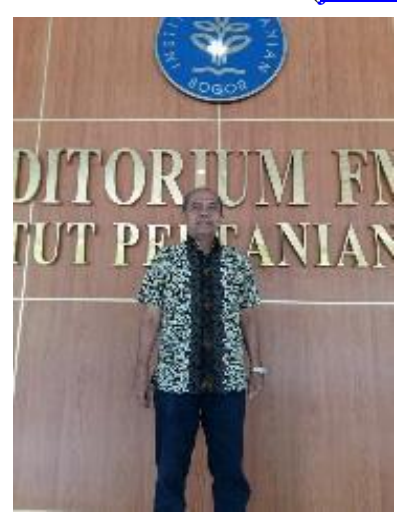

Lahir di Tahuna, Sulawesi

Utara pada tanggal 24 Agustus 1958. Pada tahun 1982 mendapatkan gelar Sarjana yang diperoleh dari Fakultas Perikanan Universitas Sam Ratulangi Manado. Pada tahun 1988 mendapatkan gelar Magister Statistika Terapan di Institut Pertanian Bogor, dan pada tahun 2006 mendapat gelar Doktor yang diperoleh dari MIPA, UNAIR Surabaya. Jabatan Akademik Profesor (Guru Besar, Statistika) sejak tahun 2007.

Hanny A. H. Komalig (hanoyo7@yahoo.com)

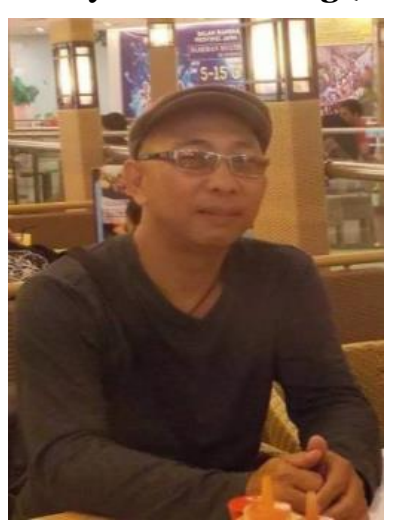

Pada tahun 1990, memperoleh gelar Insinyur di Fakultas Pertanian, Universitas Sam Ratulangi Manado. Kemudian ia mengikuti Basic Siences Bridging Program bidang Matematika di Institud Teknologi Bandung pada tahun 1992 selama 2 tahun. Selanjutnya memperoleh gelar Magister Sains bidang Statistika di Institud Pertanian Bogor tahun 1998. Dan pada tahun 2008 memperoleh gelar Doktor di Universitas Airlangga Surabaya untuk bidang Matematika Modeling. Menjadi dosen di departemen Matematika, FMIPA, Universitas Sam Ratulangi pada tahun 2000 sampai sekarang. Bidang keahlian yang ditekuni yaitu diantaranya; Statistika Multivariat Nonlinier dan Reduksi Dimensi. 